\title{
An Empirical Analysis of Factors Influencing the Production of Organic Vegetable Farming in Kerala
}

\author{
Deepa Palathingal \\ Department of Economics, Central University of Tamil Nadu, 610101, India \\ Corresponding author: deepapalathingal@gmail.com
}

\begin{abstract}
The present study examines the factors influencing the production of organic vegetable farming in the north region of Kerala. The study is based on primary data collected by using a structured questionnaire. The samples of 300 organic Vegetable farmers randomly selected from five districts of north Kerala. A logistic regression method has been used in this study to determine the factors influencing the productivity of organic vegetable farming. The results from the estimated model shows that gender, irrigation potential, sources of water, ownership of the land, experience in both farming and organic farming, land maintenance, price of organic vegetables, price volatility, farmer occupation and income source, number of household member engaged in farmingare influencing the production of organic vegetables.
\end{abstract}

Keywords: Organic Farming, production, logistic regression

"The farm itself must have biological completeness; it must have been a living entity, it must be a unit which has within itself a balanced organic life"

- Northbourne (1940, Look to the Land)

Availability of Safe, fresh and quality food has received abundant consideration in recent years due to the propagating concerns related to health and the environment (Rana, 2018). The issue started after the invention of new modern techniques in agriculture especially the green revolution. The use of synthetic fertilizer and pesticides and high yield verity of seeds has been given a huge difference in production in the initial stages accompanied by negative side effects to the environment and the people (Njeru, 2016). The conventional farming practices led the soil to infertile, polluted the water sources, made disturbances to the life cycles through killing both good and bad insects, affected climate, and sustainable development of the agriculture itself. Altieri and Anderson (1986) and Das (2017) discussed that technology changes in agriculture had adversely affected on the income distribution in rural areas and it contributed to widening the gap between different regions and small and large farmers.

Organic farming or traditional farming method is the only solution to protect our environment and sustainable development (Mccann, 1997). According to Koan (2007), organic farming is a cheap and sustainable alternative in which farmers can produce without causing health or environmental damage. It ensures the safety of food by following the traditional method and using organic manure for cultivation. According to International Food Standards, Organic farming is a holistic production management system which promotes and enhances agro-ecosystem, health, including biodiversity, biological cycles, and soil biological activity. It emphasizes the use of management practices in preference to the use of farm inputs, taking into account that regional conditions require locally, and adapted systems. This is accomplished by 
using, where possible, agronomic, biological and mechanical methods, as opposed to using synthetic materials to fulfill any specific functions within the system (WHO, 1999).

Organic farming has been considered as an alternative and healthy farming methods for small scale food producers (Njeru, 2016). Now-a-days, most of the organic farmers are not following the traditional method of farming, they mixed the traditional method with new modern technique and producing environment-friendly healthy products.

Currently, there are 50.9 million hectares of agriculture land following organic methods and 2.4 million producers were reported as certified organic farmers worldwide. Including the uncertified farmers, the number will be double and more than three-quarters of certified producers are located in developing countries. The countries with the most producers are India (585200) followed by Ethiopia (203302) and Mexico (200039) as shown in Fig. 1.

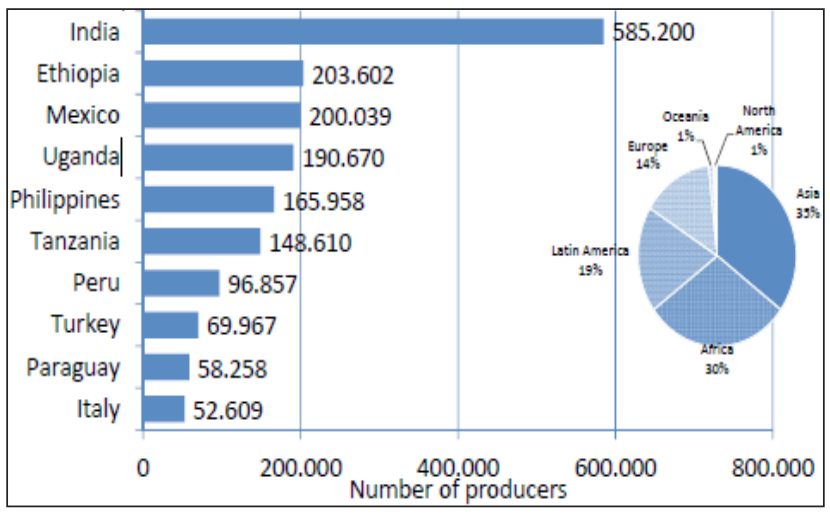

Source: FiBL Survey Report 2017

Fig. 1: The ten countries with the largest number of organic producers in 2015

There is rapid development in the adoption of organic farming during the period of 1999 to 2017 which shows in Fig 2. Currently, there are 179 countries have data on organic agriculture. Based on the recent report by IFOAM, the countries with the largest areas of organic agriculture land (million Hectares) in 2015 are Australia (2269), Argentina (307), USA (203), Spain (197), China (161), Italy (149), France (138), Uruguay (131), India (118), and Germany (109). Organic agriculture showing rapid growth in India and the organic products from India is highly demanded in world markets (reference). The survey report by FiBL shows that India coming third under ten countries shows the highest increase in organic land in 2015. So the adoption of organic farming in India is making progress rapidly.

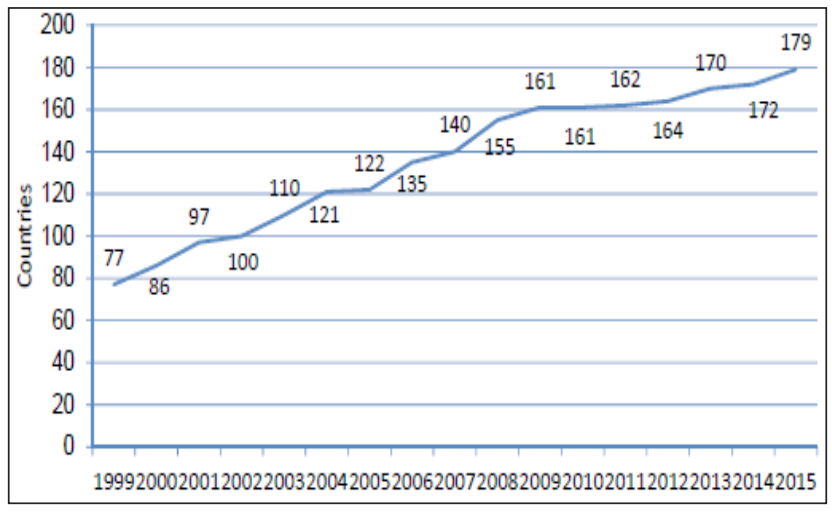

Source: FiBL Survey Report 2017.

Fig. 2: Development of the number of countries with data on organic agriculture

India followed the traditional farming method before the 1960s and the traditional agricultural practices were gradually replaced by modern technology through the green revolution (Das, 2017). Traditional farming helped the farmers to stick on locally available inputs and seeds, which kept the cost of farming low. The green revolution forced the farmers to depend on external inputs and HYV seeds, which increased the cost of farming (Sebby, 2010). This led to the booming of the credit system for agriculture and the poor farmers were trapped into the credit and finally committed suicide. The green revolution brings the chemically and mechanized farming methods in India without giving proper information and training to the local farmers about the use of inputs. This led to the unbalanced use of inputs in the field for more yield (Das, 2017) which infertile the soil and affected the health of people.

The organic farming revolution initiated in India towards the end of 1980 in a conference at Wardha by an NGO (Narayanan, 2005) as a solution for environmental issues and sustainability. Afterward, it progressed through several NGOs and, major changes occurred after the implementation of NPOP (National Programme for Organic Production) in 2000. The report of Loksabha unstarred question no 369 (2016) shows that 1443538 hector land in India is certified under organic farming and 24812 hectors in Kerala during the 2016-17 period. The major organic items exporting from India are Cereals, Cotton, Vegetables and Fruits, Oil seeds, spices, and Tea/ Coffee. 
There is a large number of studies discussed the importance of organic farming (Narayana, 2005; Remesh et al. 2005; Yadav A.K et al. 2010), the factors determine the adoption of organic farming (Lopze and Requena, 2005, Kubala et al. 2008; Sriwichailamphan et al. 2014, Ullah, 2015; Njeru, 2016; Veisi et al. 2017), comparative studies of organic and conventional farming (Wynen, 1992; Mccann,1997; Fairweather, 1999, Koesling and Lien, 2008; Kallas et al. 2009; Berg et al. 2018) etc. The studies related to determinants of productivity of organic farming are few. Therefore, the present study focused to determine the factors influence the adoption of organic vegetable farming in Kerala.

\section{Objectives of the study}

- To identify the factor determine the productivity of organic farming in northern districts of Kerala.

- To analyze the impact of the factors in the productivity of organic farming in northern districts of Kerala.

\section{Database and methodology}

The research conducted in northern districts of Kerala namely Kasargod, Kannur, Kozhikode, Wayanad, Malappuram, and Palakkad. The simple random techniques used to select the samples. The districts, block, and villages purposively selected, based on the farming area and farming techniques used in these regions. Samples of 300 organic farmers were randomly selected and the data were collected by using a structured questionnaire. The farmers have selected the study on the basis of years of adoption. Farmers who converted to organic farming less than 3 to 4 years were not included in the survey. This is because the economic benefits and productivity of organic farming can't measure in the starting of the conversion period. The primary survey collected data of basic socio-economic background of the farmer and information relevant to marketing and finance, fertilizing, irrigation aspects of organic farming.

As the productivity of organic vegetable farming is a dichotomous or binary dependent variable with the option of either higher production or lower production. Logistic regression was considered to be an appropriate analytical tool to estimate the determinants of the production of organic vegetable farming in north Kerala. In order to facilitate analysis of the data, a value of 1 was assigned to the higher production and 0 to the lower production. The parameters of the model were estimated with the maximum likelihood technique. The model has been specified as:

$$
\begin{aligned}
Y_{\mathrm{i}}=\beta_{0}+\beta_{1} X_{1}+\beta_{2} X_{2}+\beta_{3} X_{3}+\beta_{4} X_{4}+\beta_{5} X_{5}+\beta_{6} X_{6}+ \\
\beta_{7} X_{7}+\beta_{8} X_{8}+\beta_{9} X_{9}+\beta_{10} X_{10}+\beta_{11} X_{11}+\beta_{12} X_{12}+ \\
\beta_{13} X_{13}+\varepsilon
\end{aligned}
$$

\begin{tabular}{|c|c|c|c|c|c|}
\hline \multicolumn{6}{|c|}{ Description of the model variable } \\
\hline \multicolumn{6}{|c|}{\begin{tabular}{|l|l|}
$\beta_{0}$ & Intercept
\end{tabular}} \\
\hline \multicolumn{6}{|c|}{\begin{tabular}{|l|l|}
$\beta_{i}$ & The coefficients \\
\end{tabular}} \\
\hline \multirow{2}{*}{$\varepsilon$} & \multicolumn{5}{|l|}{ Error term } \\
\hline & $\begin{array}{l}\text { Dependent } \\
\text { variable }\end{array}$ & \multicolumn{4}{|l|}{ Categories } \\
\hline \multirow[t]{3}{*}{$\mathrm{Y}_{\mathrm{i}}$} & $\begin{array}{l}\text { Production } \\
\text { of organic }\end{array}$ & $\begin{array}{l}\text { Higher } \\
\text { production }\end{array}$ & 1 & & \\
\hline & $\begin{array}{l}\text { vegetable } \\
\text { farming }\end{array}$ & $\begin{array}{l}\text { Lower } \\
\text { production }\end{array}$ & 0 & & \\
\hline & $\begin{array}{l}\text { Independent } \\
\text { variables }\end{array}$ & Categories & & Legends & $\begin{array}{l}\text { Ref. } \\
\text { category }\end{array}$ \\
\hline \multirow[t]{2}{*}{$X_{1}$} & \multirow[t]{2}{*}{ Gender } & Male & 1 & Male & \multirow[t]{2}{*}{ Male } \\
\hline & & Female & 0 & Female & \\
\hline \multirow{4}{*}{$\mathrm{X}_{2}$} & \multirow{4}{*}{$\begin{array}{l}\text { The expense } \\
\text { for land } \\
\text { maintenance }\end{array}$} & 1 to 5000 & 1 & ExpLM1 & \multirow[t]{4}{*}{ NSLM } \\
\hline & & $\begin{array}{l}5001 \text { to } \\
10000\end{array}$ & 2 & ExpLM2 & \\
\hline & & \begin{tabular}{|l|}
10001 to \\
20000
\end{tabular} & 3 & ExpLM3 & \\
\hline & & $\begin{array}{l}\text { Not } \\
\text { spending }\end{array}$ & 4 & NSLM & \\
\hline \multirow[t]{2}{*}{$X_{3}$} & \multirow[t]{2}{*}{$\begin{array}{l}\text { Sources of } \\
\text { Water }\end{array}$} & $\begin{array}{l}\text { Private well/ } \\
\text { bore well }\end{array}$ & 1 & $\begin{array}{l}\text { WS Private } \\
1\end{array}$ & \multirow[t]{2}{*}{$\begin{array}{l}\text { WS Private } \\
1\end{array}$} \\
\hline & & Rainwater & 0 & $\begin{array}{l}\text { WS3 } \\
\text { rainwater }\end{array}$ & \\
\hline \multirow[t]{4}{*}{$X_{4}$} & \multirow[t]{4}{*}{$\begin{array}{l}\text { Experience in } \\
\text { organic farming }\end{array}$} & 0 to 5 & 1 & $\begin{array}{l}\text { Experience } \\
\text { OF1 }\end{array}$ & \multirow{4}{*}{$\begin{array}{l}\text { Experience } \\
\text { OF1 }\end{array}$} \\
\hline & & 5.1 to 10 & 2 & $\begin{array}{l}\text { Experience } \\
\text { OF2 }\end{array}$ & \\
\hline & & 20.1 to 30 & 3 & $\begin{array}{l}\text { Experience } \\
\text { OF4 }\end{array}$ & \\
\hline & & Above 30 & 4 & $\begin{array}{l}\text { Experience } \\
\text { OF5 }\end{array}$ & \\
\hline \multirow[t]{2}{*}{$X_{5}$} & \multirow[t]{2}{*}{$\begin{array}{l}\text { Experience in } \\
\text { farming }\end{array}$} & 0 to 5 & 1 & \begin{tabular}{|l|} 
Experience \\
F1
\end{tabular} & \multirow{2}{*}{$\begin{array}{l}\text { Experience } \\
\text { F1 }\end{array}$} \\
\hline & & 10.1 to 20 & 0 & \begin{tabular}{|l|} 
Experience \\
F3
\end{tabular} & \\
\hline \multirow{2}{*}{$X_{6}$} & \multirow{2}{*}{$\begin{array}{l}\text { Satisfaction } \\
\text { with the pricing } \\
\text { of products }\end{array}$} & Yes & 1 & SPPyes & \multirow[t]{2}{*}{ SPP yes } \\
\hline & & No & 0 & SPP no & \\
\hline
\end{tabular}

Where, 


\begin{tabular}{|c|c|c|c|c|}
\hline \multirow[t]{2}{*}{$X_{7}$} & \multirow{2}{*}{$\begin{array}{l}\text { Seasonal } \\
\text { variation in } \\
\text { pricing }\end{array}$} & Yes & 1 SVPyes & \multirow[t]{2}{*}{ SVP yes } \\
\hline & & No & 0 SVPno & \\
\hline \multirow[t]{2}{*}{$X_{8}$} & \multirow{2}{*}{$\begin{array}{l}\text { Reason for } \\
\text { conversion to } \\
\text { organic farming }\end{array}$} & $\begin{array}{l}\text { Premium } \\
\text { price }\end{array}$ & 1 Premium & \multirow[t]{2}{*}{$\begin{array}{l}\text { Premium } \\
\text { price }\end{array}$} \\
\hline & & $\begin{array}{l}\text { Other } \\
\text { factors }\end{array}$ & $\begin{array}{l}0 \text { Other } \\
\text { factors }\end{array}$ & \\
\hline \multirow[t]{3}{*}{$x$} & \multirow[t]{3}{*}{ Type of land } & Owned & 1 Owned & \multirow[t]{3}{*}{ Owned } \\
\hline & & Leased & 2 Leased & \\
\hline & & Both & 3 Both & \\
\hline \multirow[t]{3}{*}{$X_{10}$} & \multirow{3}{*}{$\begin{array}{l}\text { Occupation/ } \\
\text { sources of } \\
\text { income }\end{array}$} & Farmer & 1 Farmer & \multirow[t]{3}{*}{ Farmer } \\
\hline & & $\begin{array}{l}\text { Government } \\
\text { job/ private } \\
\text { job }\end{array}$ & 2 GJPJ & \\
\hline & & $\begin{array}{l}\text { Local job/ } \\
\text { Business/ } \\
\text { others }\end{array}$ & 3 LJBO & \\
\hline \multirow[t]{2}{*}{$X_{11}$} & \multirow{2}{*}{$\begin{array}{l}\text { Household } \\
\text { monthly } \\
\text { income }\end{array}$} & $\begin{array}{l}10000 \text { to } \\
20000\end{array}$ & 1 HM1 & \multirow[t]{2}{*}{ HM1 } \\
\hline & & $\begin{array}{l}\text { More than } \\
100000\end{array}$ & 0 HMI4 & \\
\hline \multirow[t]{2}{*}{$X_{12}$} & \multirow[t]{2}{*}{$\begin{array}{l}\text { Irrigation } \\
\text { potential }\end{array}$} & $\begin{array}{l}\text { Throughout } \\
\text { the year }\end{array}$ & \begin{tabular}{|l|l|}
1 & IP \\
throughout \\
the year
\end{tabular} & \multirow{2}{*}{$\begin{array}{l}\text { IP } \\
\text { throughout } \\
\text { the year }\end{array}$} \\
\hline & & Seasonal & 0 IP seasonal & \\
\hline $\mathrm{X}_{13}$ & $\begin{array}{l}\text { Number of } \\
\text { members in the } \\
\text { family }\end{array}$ & Measured in & Numbers & \\
\hline
\end{tabular}

\section{RESULTS AND DISCUSSION}

\section{Socio-economic and farm characteristics of the respondents}

Table 1 shows the Socioeconomic and farm characteristics of the respondents in the study. The results show that the organic sector slightly dominated by men (53.7\%) however, the figure shows higher female participation in organic farming. Among the respondents, $72 \%$ of farmers are coming under labor groups as per age classification. The highest number of farmers are coming under 41 to 60 age group, which is coming $53.7 \%$ of the total number of farmers. The majority of farmers not well educated they are coming $66.7 \%$ of the total farmers and out of that $1.3 \%$ of the farmers are illiterate and $65.4 \%$ has been completed education up to primary classes. There are only $15.7 \%$ of farmers are graduates. $80.7 \%$ of the respondents were married. In the sample size, 65.3 percentage of farmers are full-time farmers and in addition to farming 15.3 percent are engaged in some local jobs, 11.3 percent and government employees, $5 \%$ are doing private jobs and $3 \%$ doing business too. The table shows that more than half of the farmers are engaged in full-time farming. Among the total respondents, $37.7 \%$ are coming under the income class between $₹ 10000$ to $₹ 20000$ per month and $49 \%$ are between ₹ 20001 to ₹ 60000 . There are $13.4 \%$ belongs to more than ₹ 60000 per month. Considering the farm characteristics of the respondents, $47 \%$ cultivate in a leased land, 26.3\% in both owned and leased land and $26.7 \%$ in owned land. The availability of water is much better in the study areas. It is reported that $45.7 \%$ of farmers were getting full-time water availability and $48.7 \%$ dependent on seasonal. The state has an advantage of the rainy season for 6 months. There are $41.3 \%$ of farmers were doing agriculture activities between 5 to 20 year and $17 \%$ of farmers got the experience between 21 to 30 years. The farmers having experience above 31 years are $29 \%$. This shows that most of the farmers in the sample were highly experienced in farming. Those farmers (33.7) who can be coming under the experience in organic farming were 5.1 to 10 years of experience and 21.6 percentage of farmers having more than 20 years of experience. Around $28 \%$ of farmers were still in the conversion period of 0 to 5 years. The majority of farmers in samples hold livestock $(62 \%)$. The majority of farmers depend on own capital for farming activities and $41.3 \%$ depends on financial institutions. Only $7.7 \%$ of farmers found other sources for finance.

Table 1: Frequency and percentage distribution of the respondents according to Socioeconomic and farm characteristics

\begin{tabular}{cccc}
\hline Character & & Frequency & Percentage \\
\hline Gender & Male & 161 & 53.7 \\
& Female & 139 & 46.3 \\
\hline Education & Illiterate & 4 & 1.3 \\
& Less than & 98 & 32.7 \\
& Primary & & \\
& Primary & 98 & 32.7 \\
& Secondary & 42 & 14 \\
& Graduation & 47 & 15.7 \\
& Other & 11 & 3.7 \\
\hline Marital Status & Single & 33 & 11 \\
& Married & 242 & 80.7 \\
& Divorced & 25 & 8.3 \\
\hline Age & 20 to 40 & 56 & 18.7 \\
& 41 to 60 & 160 & 53.3 \\
& 61 to 80 & 83 & 27.7 \\
& 81 to 100 & 1 & 0.3 \\
\hline
\end{tabular}




\begin{tabular}{|c|c|c|c|}
\hline \multirow[t]{5}{*}{ Occupation } & $\begin{array}{l}\text { Full-time } \\
\text { farming }\end{array}$ & 196 & 65.3 \\
\hline & Local job & 46 & 15.3 \\
\hline & $\begin{array}{l}\text { Government } \\
\text { job }\end{array}$ & 34 & 11.3 \\
\hline & Private job & 15 & 5.0 \\
\hline & Business & 9 & 3.0 \\
\hline \multirow{4}{*}{$\begin{array}{l}\text { Income of } \\
\text { household } \\
\text { (monthly) }\end{array}$} & 10000 to 20000 & 113 & 37.7 \\
\hline & 20001 to 60000 & 147 & 49 \\
\hline & $\begin{array}{c}60001 \text { to } \\
100000\end{array}$ & 29 & 9.7 \\
\hline & $\begin{array}{c}\text { More than } \\
100000 \\
\end{array}$ & 11 & 3.7 \\
\hline \multirow{3}{*}{$\begin{array}{l}\text { Ownership of } \\
\text { Land }\end{array}$} & Owned & 80 & 26.7 \\
\hline & Leased & 141 & 47 \\
\hline & Both & 79 & 26.3 \\
\hline \multirow[t]{3}{*}{$\begin{array}{l}\text { Irrigation } \\
\text { Potential }\end{array}$} & $\begin{array}{c}\text { Throughout } \\
\text { the year }\end{array}$ & 137 & 45.7 \\
\hline & Seasonal & 146 & 48.7 \\
\hline & Not assured & 17 & 5.7 \\
\hline \multirow{5}{*}{$\begin{array}{l}\text { Experience in } \\
\text { farming }\end{array}$} & 4 to 5 & 38 & 12.7 \\
\hline & 5.1 to 10 & 63 & 21.0 \\
\hline & 10.1 to 20 & 61 & 20.3 \\
\hline & 20.1 to 30 & 51 & 17 \\
\hline & Above 30 & 87 & 29 \\
\hline \multirow{5}{*}{$\begin{array}{l}\text { Experience in } \\
\text { organic farming }\end{array}$} & 4 to 5 & 84 & 28 \\
\hline & 5.1 to 10 & 101 & 33.7 \\
\hline & 10.1 to 20 & 50 & 16.7 \\
\hline & 20.1 to 30 & 34 & 11.3 \\
\hline & Above 30 & 31 & 10.3 \\
\hline \multirow[t]{6}{*}{ Livestock } & $\begin{array}{c}\text { Cattle/Goat/ } \\
\text { Piggery/rabbit }\end{array}$ & 137 & 45.7 \\
\hline & Poultry/Duck & 29 & 9.7 \\
\hline & Bee Keeping & 6 & 2.0 \\
\hline & Fish & 9 & 3 \\
\hline & Others & 5 & 1.7 \\
\hline & $\begin{array}{l}\text { No allied } \\
\text { activities } \\
\end{array}$ & 114 & 38 \\
\hline \multirow{2}{*}{$\begin{array}{c}\text { Membership of } \\
\text { organization }\end{array}$} & Yes & 153 & 51 \\
\hline & no & 147 & 49 \\
\hline \multirow[t]{4}{*}{ Finance } & Own capital & 153 & 51 \\
\hline & $\begin{array}{l}\text { Finance } \\
\text { institutes }\end{array}$ & 124 & 41.3 \\
\hline & Relative & 9 & 3 \\
\hline & Others & 14 & 4.7 \\
\hline
\end{tabular}

Source: Field survey 2018.

The maximum likelihood estimates of the parameters in the logistic regression model characterizing the behavior of organic farmers towards the productivity of organic farming shown in Table 2. All variables are statistically significant at $5 \%$ level $(\mathrm{p}<.05)$. The odds ratio shows in column two of the table.
The results show that in organic vegetable farming in north Kerala, female farmers having higher production compared to male farmers as the odds ratios is greater one (3.351). The government policies in Kerala towards the development of organic farming is female-centric, the government trying to popularize the benefits of organic farming through women self-help groups called Jaivasree and Kudumbashree in Kerala. This may be a reason for higher production for female farmers. some of the studies argue (Desai, 2013; Farnworth, 2009; Roy et al. 2015) that accessibility of chemical is comparatively less for female farmers and the concentration of farming on family needs than marketing is also a factor of higher production in female farmers.

Experience is a major factor in determining the productivity of a farmer. Experienced farmers can find their own way to maximize production with minimum inputs. In this study, included three dummies in the model. The odds ratio for Experience OF2, Experience OF4 and Experience OF5 are $1.9758,2.9306,3.8307$ respectively, are greater than one. Which means that It indicates that a farmer having more years of experience in both farming and organic farming are more likely to produce higher than the farmer with less experience in farming and organic farming.

The irrigation potential and water source is another important factor to help in the production of farming. The farmers are getting more rainfall in a year and having irrigation potential throughout the year are more likely to have higher production than the farmers depending on private water sources and seasonal irrigation facility. The odds ratios of seasonal irrigation potential and rainwater are 0.2202 and 4.8371 respectively, which are greater than one.

Usually, the vegetable market faces higher volatility and unpredictable risk in the pricing of the products. This is a major demotivating factor all the farmers. But in the case of organic farming, consumers are ready to pay a higher price for the quality product and the volatility in pricing is comparatively low which encourage the farmers to convert into organic farming. The present study shows that farmers converted to organic farming due the attractive premium price are more likely to produce higher than the farmers converted due to other factors like 
social commitment and health motives, as the odds ratio of other factors for conversion is less than one (0.0701). In the same aspect, the odds ratio of not satisfied with pricing (0.2109) and no seasonal variation in pricing (2.686) point out that, farmers satisfied with the pricing of their product and farmers facing no seasonal variation for prices are also highly motivated and producing higher than their counterparts.

In most of the farming family, household members are substituted as labor for farm activities. This may help the farmer to reduce the cost of production by cutting down the wage rate. But the current study found that increasing the participation of household members in organic farming reduces the chances of having higher organic vegetable production. This may be due to the lack of skill development of household laborer.

The ownership of the land and farmers sources of income are also influencing the production of organic vegetable farming. The odds ratio of leased land (0.3857) and both leased and owned land (0.4371) shows that farmers cultivating in owned land are more likely to produce higher than the farmers cultivating in leased land. Farmers are getting more chances and interest to improve the fertility of the land,in owned land than leased land. This is because it will take years to convert the land into fully organically fertile, so a farmer depends on leased land cannot get a long period to convert the land into fully organic. The main drawback of organic farming is the problem adoption period of land to the organic. In these adoption periods, the productivity of land will very less. So, these features point out that farmers having own land get enough time to convert their land and getting higher production.

The farmers having other sources of income and higher household monthly income may spend less time and interest in farming compared to the farmers depend on farming as an income source. The results show that the odds ratio for Local job /business and others (LJBO) and Government job/ private job are 0.3486 and 0.2981 respectively, both are lesser than one. This means that the organic farmers engaged in other jobs are more likely to produce less organic products compared to the farmers full time engaged with farming. The odds ratio for household monthly income 4 (HM4) is 0.1444 is less than one. This means that the farmers having higher monthly income are more likely to produce lesser output compare to the farmer having a low monthly income.

The expenses for land maintenance is another important factor induce the production of organic vegetable farming. The odds ratio for ExpLM3, ExpLM2 and ExpLM1 are 39.28941, 10.56228 and 14.3522 respectively. This indicates that farmers spending for land maintenance is more likely to have higher production, compared to farmers not spending for land maintenance. Maintaining farmland will induce fertility of the land, this will help to induce the productivity of the land.

Table 2: Results of logistic regression

\begin{tabular}{|c|c|c|}
\hline \multicolumn{3}{|l|}{ Number of obs $=299$} \\
\hline \multicolumn{3}{|l|}{$\operatorname{LR}_{\operatorname{chi}^{2}}(23)=124.34$} \\
\hline \multicolumn{3}{|l|}{ Prob $>$ chi $^{2}=0.0000$} \\
\hline \multicolumn{3}{|l|}{ Pseudo R2 = 0.3033} \\
\hline \multicolumn{3}{|l|}{ Log likelihood = -142.78544 } \\
\hline y1 & Odds Ratio & $P>|z|$ \\
\hline Female & 3.351092 & 0.004 \\
\hline ExpLM3 & 39.28941 & 0.001 \\
\hline WS3 Rainwater & 4.837187 & 0.021 \\
\hline Experience OF5 & 3.830717 & 0.017 \\
\hline SPP no & .2109645 & 0.000 \\
\hline ExpLM2 & 10.56228 & 0.040 \\
\hline SVP no & 2.686712 & 0.015 \\
\hline Number of organic farmers & .7779248 & 0.029 \\
\hline Other factors of conversion & .0701292 & 0.000 \\
\hline Leased & .3857574 & 0.031 \\
\hline Both & .4371616 & 0.059 \\
\hline Experience OF4 & 2.930685 & 0.045 \\
\hline LJBO & .3486728 & 0.024 \\
\hline GJPJ & .2981312 & 0.005 \\
\hline ExpLM1 & 14.3522 & 0.021 \\
\hline HMI4 & .1444759 & 0.028 \\
\hline Experiece OF2 & 1.97588 & 0.052 \\
\hline IP Seasonal & .2202004 & 0.000 \\
\hline ExperienceF3 & 2.632134 & 0.016 \\
\hline _cons & 1.175985 & 0.897 \\
\hline
\end{tabular}

Source: author calculations.

\section{CONCLUSION}

The production of organic vegetable farming induced by various factors includes the gender of the farmer, irrigation potential, sources of water, 
ownership of the land, experience in both farming and organic farming, land maintenance etc. The study points out that, female farmers, farmers cultivate in owned land, farmers having more years of experience, farmers availing higher rainfall and irrigation facility throughout the year are having higher production compared to counterparts. Some other factors like getting higher price products, low volatility in pricing motivate the farmers positively to stick with organic farming. The study shows that farmers converted to organic farming for looking towards the premium price are having higher production than farmers converted due to other factors like social commitment and health motives. The farmers having other income sources and jobs and higher household monthly income are less likely to concentrate to increase the production of organic vegetable farming. The farmer will hire labor to depend on the availability of household member for the farm activity. This action may help to reduce the cost of production of farming, but the results show that unskilled labor from the household may lead to a reduction in total production.

Conflict of interest statement: The author declare that there is no conflict of interest.

\section{REFERENCES}

Altieri, M.A. \& Anderson, M.K. 1986. An ecological basis for the development of alternative agricultural systems for small farmers in the Third World. American Journal of Alternative Agriculture, 1(1): 30-38.

Bisoyi,B. \& Das, B. 2017. Organic Farming: A Sustainable Environmental ingenuity for Biotechnological intervention towards a Green World. Organic Farming, 6(9).

Berg, H., Maneas, G. \& Salguero Engstrom, A. 2018. A Comparison between Organic and Conventional Olive Farming in Messenia, Greece. Horticulture, 4(3): 15.

Desai, R.M. 2017. Role of women in organic farming and their family quality index in the selected agro-climatic zones of Northern Karnataka (Doctoral dissertation, UASD).

Fairweather, J.R. 1999. Understanding how farmers choose between organic and conventional production: Results from New Zealand and policy implications. Agriculture and Human Values, 16(1): 51-63.

Farnworth, C. \& Hutchings, J. 2009. Organic agriculture and women's empowerment. IFOAM, Germany, 86.

KOAN. 2007. Kilimohai, Guaranteeing Organic Quality, 1(3): 10-11.

Koesling, M., Flaten, O. \& Lien, G. 2008. Factors influencing the conversion to organic farming in Norway. International Journal of Agriculture Resources; Governance and Ecology, 7(1-2): 78-95.
Kubala, J., Grodzinska- Jurczak, M., Cichon, M. \& Nieszporek, K. 2008. Motivations for organic farming among farmers from Malopolska Province, Poland. International Journal of Environment and Sustainable Development, 7(3): 345-361.

Kallas, Z., Serra, T. \& Gil, J.M. 2010. Farmers' objectives as determinants of organic farming adoption: the case of Catalonian vineyard production. Agricultural Economics, 41(5): 409-423.

Lord Northbourne. 2003. Look to the Land. Sophia Perennis.

Lopez, C.P. \& Requena, J.C. 2005. Factors related to the adoption of organic farming in Spanish olive orchards. Spanish Journal of Agricultural Research, 3(1): 5-16.

Mccann, E., Sullivan, S., Erickson, D. \& De Young, R. 1997. Environmental awareness, economic orientation, and farming practices: a comparison of organic and conventional farmers. Environmental Management, 21(5): 747-758.

Narayanan, S. \& Narayanan, S. 2005. Organic farming in India: relevance, problems, and constraints. National bank for Agriculture and Rural Development.

Njeru, M.K. 2016. Factors influencing adoption of organic farming among farmers in Nembure Division, Embu Country- Kenya. American International Journal of Contemporary Research, 6: 90-96.

Ramesh, P., Singh, M. \& Rao, A.S. 2005. Organic farming: Its relevance to the Indian context. Current Science, 88(4): 561-568.1

Roy, S. \& Mondal, S. 2015. Women's involvement in organic (Vegetables) Farming System Activities (OFSA) in Samsung district of North- East Thailand. IOSR Journal of Humanities and Social Science, 20(7): 8-13.

Rana, S.S. 2016. Organic farming. Department of Agronomy, College of Agriculture, CSK Himachal Pradesh Krishi Vishvavidyalaya, Palampur, pp. 90

Sebby, K. 2010. The Green Revolution of the 1960s and its impact on Small Farmers in India.

Sriwichailamphan, T. \& Sucharidthan, T. 2014. Factors Affecting Adoption of Vegetable Growing Using Organic System: A Case Study of Royal Project Foundation, Thailand. Int. J. Econ. Manag. Sci., 3(179): 2.

Ullah, A., Shah, S.N.M., Ali, A., Naz, R., Mahar, A. \& Kalhoro, S.A. 2015. Factors affecting the adoption of organic farming in Peshawar- Pakistan. Agricultural Science, 6(06): 587.

Veisi, H., Carolan, M.S. \& Alipour, A. 2017. Exploring the motivations and problems of farmers for conversion to organic farming in Iran. International Journal of Agricultural Sustainability, 15(3): 303-320.

Wynen, E. 1992. Conversion from Conventional to Organic Agriculture. Wynen.

World Health Organization. 1999. High-Dose Irradiation: Wholesomeness of Food Irradiated with Doses above $10 \mathrm{kGy}$ (No.890). World Health Organization.

Willer, H. \& Lernoud, J. 2017. FiBL survey on Organic Agriculture Worldwide- Metadata. In The World of Organic 
Agriculture-Statistics and Emerging Trends 2017 (pp.296306). Research Institute of Organic Agriculture (FiBL) and IFOAM- Organics International.

Yadav, A.K. 2010. Organic Agriculture (Concept, Scenario, Principals, and Practices). Director National Centre of
Organic farming, Ghaziabad National Centre of Organic Farming Department of Agriculture and Cooperation, Ministry of Agriculture, Govt on India, Uttar Pradesh. 